Original Research Article

\title{
Antibiotic resistance and usage, a survey on the knowledge, attitude and practices among the medical students of a southern Indian teaching hospitals
}

\author{
Swathi Ratnam Regidi ${ }^{1}$, Billa S. B. Mallika ${ }^{2 *}$
}

${ }^{1}$ Department of Pharmacology, Government Medical College, Balaga, Srikakulam, Andhra Pradesh, India ${ }^{2}$ Department of pharmacology, Rangaraya Medical College, Opp. Government General Hospital, Andhra Pradesh, India

Received: 08 March 2019 Accepted: 08 April 2019

*Correspondence to: Dr. Billa S. B. Mallika, Email: mallipharma@ rediffmail.com

Copyright: () the author(s), publisher and licensee Medip Academy. This is an openaccess article distributed under the terms of the Creative Commons Attribution NonCommercial License, which permits unrestricted noncommercial use, distribution, and reproduction in any medium, provided the original work is properly cited.

\begin{abstract}
Background: Examining the knowledge, attitude and practices (KAP) of the medical students regarding antibiotic resistance (ABR) and use can help us in devising suitable educational interventions for them, tailored according to their earlier held knowledge, beliefs, capabilities and experience.

Methods: A cross sectional, questionnaire based survey was conducted among medical students of a teaching hospital, whereby their KAP regarding antibiotic use and resistance was assessed by using a questionnaire, whose responses ranged from 'agree' to 'disagree,' 'always to never' and true / false. The data was analysed by using simple descriptive statistics. Wherever it was relevant, the Chisquare test was used to determine any significant difference.

Results: The number of medical students who agreed that ABR was an important and a serious public health issue in this teaching hospital was 76 percent $(\mathrm{n}=$ $325)$. But, only $54.3 \%(\mathrm{n}=233)$ of the students were aware that bacteria were not responsible for causing cold and flu, while the remaining 37.2 percent $(n=22)$ were not knowledgeable about this fact. More than $80 \%$ rated the adverse effect profile of the antibiotic and the risk of a super infection as the important factors which deserved consideration. Cost of the antibiotic was considered to be an important factor deserving consideration by only $65.5 \% \quad(n=277)$ of the participants.

Conclusions: Our survey revealed that most of the students were aware of the antimicrobial resistance and its consequences. The only concern was their casual attitude regarding the antibiotic use. Further educational interventions are necessary to improve their understanding and perceptions on antibiotic resistance, as well as their attitude towards antibiotic use.
\end{abstract}

Keywords: Attitude, Antibiotics, Antimicrobial resistance, Knowledge, Medical students, Practice

\section{INTRODUCTION}

The threat of antimicrobial resistance is rapidly progressing and intensifying. The awareness on its seriousness and significance is the first step towards decreasing its progress. Various approaches have been taken worldwide, to meet the challenges which are posed by its spread. One of the approaches which is commonly suggested is to undertake instructional and educational campaigns among the general population as well as among the health care personnel about antibiotic resistance and its dangerous consequences and regarding the steps which can limit its development and spread. ${ }^{1-4}$ 
Prescribers have an important role to play in the battle against antibiotic resistance, not only through their safe and rational prescribing, but also by promoting patient awareness, knowledge and imparting health education to the community regarding safe medication practices concerning antibiotics.

Various studies have described the inability of the prescribing physicians in creating awareness and providing adequate education to the patients regarding antibiotic usage. ${ }^{1}$

The lack of adequate training during their undergraduate and postgraduate years may be responsible for their inability to undertake these tasks confidently. Hence, teaching about antibiotics should form a vital part of both the undergraduate and postgraduate medical curricula, considering the frequency with which these agents are prescribed and our continuing and increasing concern regarding antibiotic resistance. ${ }^{5}$

It has been greatly emphasised that adequate training should be provided for the undergraduate medical, pharmacy and nursing students regarding the proper prescribing, dispensing and the usage of antibiotics respectively.

It is an important measure which is widely proposed and documented, in order to promote the judicious use of antibiotics. $^{6}$

Young doctors should be given more education during their undergraduate training regarding antibiotic resistance and appropriate prescribing. This is a crucial time period during which the importance of these issues should be emphasized, because once the doctors become qualified, it is difficult to change their deeply entrenched views and behaviour. $^{7}$

The interventions which are undertaken to prevent and control antimicrobial resistance, usually aim to bring about behavioural changes in the target group, and the outcome of these interventions is affected by the previous beliefs and motivations which are held by this group. ${ }^{8}$

Hence, for any educational intervention to be successful and for the changes to be sustained, it should change the knowledge, attitudes and practices (KAP) of the target group. ${ }^{9}$

Therefore, before planning any training programme or an educational activity, we have to be aware of the baseline KAP of the target population, which will assist us in devising a suitable approach and an effective curriculum.

It is in this regards that this study was undertaken among medical students, in order to assess their knowledge and attitude concerning antibiotic resistance, as well as their self reported practices which are related to antibiotic usage.
A better understanding of what the students know and believe about the issues of antimicrobial use and resistance can assist us in planning and devising an effective and a tailored educational intervention for them.

\section{METHODS}

This study was a cross-sectional, questionnaire based survey which was undertaken in a Government Medical College, Srikakulam among MBBS students. The questionnaire which we used was developed by modifying the earlier ones which were used by Wester CW et al, and others. ${ }^{10-13}$ Prior to the study, the questionnaire was validated by subject experts for its content and relevance. The final questionnaire consisted of 24 questions (Annexure 1). The participants knowledge was assessed by using a set of 12 questions. These were of the True/False type. A 3-point Likert scale, whose responses ranged from 'agree' to 'disagree' was used, both to assess the student's perceptions on the causes of ABR, as well as the factors which influenced their decision about the antibiotic selection and prescribing. Their self reported Medication practices regarding antibiotic usage were also assessed by using a Likert scale which scale which ranged from 'always' to 'never'.

Inclusion criteria being MBBS students of Government Medical College, Srikakulam. While First Year MBBS students (as they were not exposed to Pharmacology subject), those who have not given consent and questionnaire are excluded from the study. The questionnaire was distributed to 500 medical students. They were asked to complete the questionnaire anonymously. Informed consent was obtained from the participants, to utilize their data for research purposes.

Simple descriptive statistics was used to generate frequencies, percentages and proportions. Wherever it was relevant, the Chi-square test was used to determine any statistical significance.

\section{RESULTS}

Among 500 students, only 429 students participated in the survey. $75 \%$ students agreed that ABR was an important and a serious public health issue in this hospital $(n=325)$.

More than $85 \%$ of the students agreed that an indiscriminate and an injudicious use of antibiotics could lead to an ineffective treatment, increased adverse effects, the emergence of bacterial resistance and an additional burden of medical costs to the patient.

A majority, $78 \%(n=333)$ students were aware that if antibiotics were taken too often, they are less likely to work in the future. Only $73 \%(n=306)$ of the students were aware that bacteria were not responsible for causing cold and flu, while the remaining $27 \%(\mathrm{n}=116)$ were not knowledgeable about this fact. 
Table 1: Students knowledge regarding antibiotic use and resistance.

\begin{tabular}{|c|c|c|c|c|c|c|c|}
\hline $\begin{array}{l}\text { S. } \\
\text { No. }\end{array}$ & Survey Item & $\begin{array}{l}\text { Important } \\
\text { (n) }\end{array}$ & $\begin{array}{l}\text { Impt } \\
(\%)\end{array}$ & $\begin{array}{l}\text { Unsure } \\
\text { (n) }\end{array}$ & $\begin{array}{l}\text { Unsure } \\
(\%)\end{array}$ & $\begin{array}{l}\text { Unimportant } \\
\text { (n) }\end{array}$ & $\begin{array}{l}\text { Unimpt } \\
(\%)\end{array}$ \\
\hline 1 & $\begin{array}{l}\text { Indiscriminate antimicrobial use leads } \\
\text { to the emergence of the growing } \\
\text { problem of resistance }\end{array}$ & 260 & 60.6 & 58 & 13.5 & 111 & 25.9 \\
\hline 2 & $\begin{array}{l}\text { Antimicrobial resistance means that if } \\
\text { they are taken too often, antimicrobials } \\
\text { are less likely to work in the future }\end{array}$ & 333 & 77.6 & 22 & 5.13 & 74 & 17.2 \\
\hline 3 & $\begin{array}{l}\text { Bacteria cause common cold and } \\
\text { influenza }\end{array}$ & 306 & 71.3 & 116 & 27 & 7 & 1.63 \\
\hline 4 & $\begin{array}{l}\text { Antibiotic Resistance is an important } \\
\text { and serious global public health issue }\end{array}$ & 325 & 75.8 & 48 & 11.2 & 56 & 13.1 \\
\hline 5 & $\begin{array}{l}\text { Ineffective treatment can occur due to } \\
\text { indiscriminate and injudicious } \\
\text { antimicrobial use }\end{array}$ & 394 & 91.8 & 28 & 6.53 & 7 & 1.63 \\
\hline \multirow{3}{*}{6} & Antibiotic resistance leads to & & & & & & \\
\hline & Increased adverse effect & 369 & 86 & 22 & 5.13 & 38 & 8.86 \\
\hline & Additional burden of medical cost & 277 & 64.6 & 111 & 25.9 & 41 & 9.56 \\
\hline 7 & $\begin{array}{l}\text { Do you think there is abuse of } \\
\text { antibiotics }\end{array}$ & 44 & 10.3 & 199 & 46.4 & 186 & 43.4 \\
\hline 8 & $\begin{array}{l}\text { Is efficacy better, if antibiotics are } \\
\text { newer and costlier }\end{array}$ & 178 & 41.5 & 219 & 51 & 32 & 7.46 \\
\hline 9 & $\begin{array}{l}\text { It is necessary to educate the medical } \\
\text { fraternity and society regarding } \\
\text { Antimicrobial Resistance? }\end{array}$ & 367 & 85.5 & 40 & 9.32 & 22 & 5.13 \\
\hline 10 & $\begin{array}{l}\text { Implementation of strict rules for } \\
\text { rational use of antibiotics }\end{array}$ & 289 & 67.4 & 70 & 16.3 & 70 & 16.3 \\
\hline 11 & $\begin{array}{l}\text { Is Pharmcovigilance relevant to this } \\
\text { topic? }\end{array}$ & 47 & 11 & 294 & 68.5 & 88 & 20.5 \\
\hline 12 & $\begin{array}{l}\text { Consideration of Pharmacoeconomic } \\
\text { burden on the patient, family, society, } \\
\text { country and globally because of } \\
\text { irrational use of Antibiotics }\end{array}$ & 198 & 46.2 & 211 & 49.2 & 20 & 4.66 \\
\hline
\end{tabular}

$\mathrm{n}=$ number of students

Table 2: Students attitude regarding antibiotic use and resistance.

\begin{tabular}{|llllllll|}
\hline $\begin{array}{l}\text { S. } \\
\text { No. }\end{array}$ & Survey Item & $\begin{array}{l}\text { Agree } \\
\text { (n) }\end{array}$ & $\begin{array}{l}\text { Agree } \\
(\%)\end{array}$ & $\begin{array}{l}\text { Uncertain } \\
(\mathbf{n})\end{array}$ & $\begin{array}{l}\text { Uncertain } \\
(\%)\end{array}$ & $\begin{array}{l}\text { Disagree } \\
\text { (n) }\end{array}$ & $\begin{array}{l}\text { Disagree } \\
(\%)\end{array}$ \\
\hline 13 & $\begin{array}{l}\text { Antibiotics are safe drugs, hence they } \\
\text { can be commonly used medication }\end{array}$ & 247 & 57.6 & 114 & 26.57 & 68 & 15.850816 \\
\hline 14 & $\begin{array}{l}\text { Skipping one or two doses does not } \\
\text { contribute to the development of } \\
\text { antibiotic resistance }\end{array}$ & 282 & 65.7 & 62 & 14.45 & 85 & 19.81352 \\
\hline 15 & $\begin{array}{l}\text { Adverse effects of antimicrobials are } \\
\text { reduced by using more than one } \\
\text { antimicrobial at a time }\end{array}$ & 144 & 33.6 & 266 & 62 & 19 & 4.4289044 \\
\hline $\begin{array}{l}\text { When you have a cough and sore } \\
\text { throat, antimicrobials are the first } \\
\text { drug of choice for early treatment and } \\
\text { to prevent emergence of resistant } \\
\text { strains }\end{array}$ & 295 & 68.8 & 96 & 22.38 & 38 & 8.8578089 \\
\hline 17 & $\begin{array}{l}\text { In the coming decades antibiotic } \\
\text { resistance cases will be more than the } \\
\text { cancer cases }\end{array}$ & 122 & 28.4 & 185 & 43.12 & 122 & 28.438228 \\
\hline
\end{tabular}

$\mathrm{n}=$ number of students 
Table 3: Students self reported practices regarding the antibiotic use.

\begin{tabular}{|c|c|c|c|c|c|c|c|}
\hline $\begin{array}{l}\text { S. } \\
\text { No. }\end{array}$ & Survey Item & $\begin{array}{l}\text { Always } \\
\text { (n) }\end{array}$ & $\begin{array}{l}\text { Always } \\
(\%)\end{array}$ & $\begin{array}{l}\text { Sometimes } \\
\text { (n) }\end{array}$ & $\begin{array}{l}\text { Sometimes } \\
(\%)\end{array}$ & $\begin{array}{l}\text { Never } \\
\text { (n) }\end{array}$ & $\begin{array}{l}\text { Never } \\
(\%)\end{array}$ \\
\hline 18 & $\begin{array}{l}\text { Do you consult a doctor before starting } \\
\text { an antibiotic? }\end{array}$ & 148 & 34.5 & 119 & 27.7 & 162 & 37.8 \\
\hline 19 & $\begin{array}{l}\text { The Doctor prescribes a course of } \\
\text { antibiotic for you. After taking } 2-3 \\
\text { doses you start feeling better, Do you } \\
\text { stop taking the further treatment? }\end{array}$ & 128 & 29.8 & 112 & 26.1 & 189 & 44.1 \\
\hline 20 & $\begin{array}{l}\text { Do you save the remaining antibiotics } \\
\text { for the next time you get sick? }\end{array}$ & 244 & 56.9 & 116 & 27 & 69 & 16.1 \\
\hline 21 & $\begin{array}{l}\text { Do you discard the remaining, left } \\
\text { over medication? }\end{array}$ & 69 & 16.1 & 116 & 27 & 244 & 56.9 \\
\hline 22 & $\begin{array}{l}\text { Do you give the leftover antibiotics to } \\
\text { your friend/roommate if they get sick? }\end{array}$ & 215 & 50.1 & 121 & 28.2 & 93 & 21.7 \\
\hline 23 & $\begin{array}{l}\text { Do you complete the full course of } \\
\text { treatment? }\end{array}$ & 189 & 44.1 & 112 & 26.1 & 128 & 29.8 \\
\hline 24 & $\begin{array}{l}\text { Do you check the expiry date of the } \\
\text { antibiotic before using it? }\end{array}$ & 405 & 94.4 & 19 & 4.43 & 5 & 1.17 \\
\hline
\end{tabular}

$\mathrm{n}=$ number of students

The knowledge, attitudes and the self reported practices of the students, which pertained to antibiotic use and resistance were examined on a Likert scale, the results of which are shown in the (Table 1) (Table 2) and (Table 3) respectively.

A list of factors which had to be considered before prescribing an antibiotic were provided and the students were asked to rate them according to the importance which they felt that these factors deserved. More than $80 \%$ of them gave importance to the adverse effect profile of the antibiotic and the risk of a super infection as well as the immune status of the patient. Nearly $61 \%(n=260)$ of the participants felt that the following factors were important to be considered- the ability of the antibiotic to promote resistance, the in-vitro antibiotic sensitivity of the causative organism and the pharmacokinetic profile of the antibiotic. Only $66 \%(\mathrm{n}=277)$ participants felt that the cost was an important factor which deserved consideration before the prescription of an antibiotic.

\section{DISCUSSION}

This study provides useful information about the knowledge, attitudes and the practices of medical students with respect to antibiotic resistance and usage, which may be utilized to plan suitable educational interventions that aim at improving the antimicrobial prescribing and use.

A majority of the students in this study were well aware of the global as well as the nationwide problem of antimicrobial resistance, but at the local hospital level, the antibiotic resistance was not considered to be a problem, similar to Thriemer $\mathrm{K}$ et al, and Sellman JS et al, studies. ${ }^{14,15}$ Case vignettes which illustrate the harmful effects of antibiotic resistance, may be utilized to improve the effectiveness of educational interventions that were previously used less successfully, to facilitate the correct estimation of the prevalence of the resistance at the institutional level.

The attitude of the study participants with regards to antibiotic use and resistance was found to be casual. $68.8 \%$ $(n=295)$ of them reported that antibiotics should be taken on developing a cold and believed that taking antibiotics on having a cold made them feel better more quickly. $57.6 \%(n=247)$ participants believed that antibiotics were safe drugs; and that hence, they could be commonly used and $71.3 \%(n=306)$ were not knowledgeable of the fact that bacteria were not responsible for causing cold and flu.

Various studies have similarly reported that more than $60 \%$ of their participants believed that antibiotics should be prescribed for viral illnesses. Such wrong beliefs may lead to inappropriately high rates of antibiotic consumption, which can result in a corresponding increase in the bacterial resistance. $34.5 \%(n=148)$ of students always consulted a doctor before starting on an antibiotic and only $44.1 \%(n=189)$ always completed the full course of the prescribed treatment.

Zafar SN et al, study has shown high rates of self medication $(35 \%)$ amongst medical students with respect to antibiotics. ${ }^{16}$ which is similar to our study.

When they were asked to mention the important causes of antimicrobial resistance, most of them stated that mutational and evolutionary changes in the microorganism and lack of restrictions on the antibiotic usage as very important causes. As in some previous studies, poor or lack 
of infection control measures were not considered to be an important cause for the resistance to develop, by most of the participants, which highlighted the lack of awareness regarding the significance of the infection control measures.

Nathwani D et al, study shows the failure in implementing basic infection control practices has been one of the principles causes of the emergence and the dissemination of resistant organisms. ${ }^{17}$

Davey $\mathrm{P}$ et al, study analysis shows learning about the antimicrobial prescribing in pharmacology must be connected clearly with the infection control in microbiology. ${ }^{18}$ The significance of simple measures like hand hygiene in the control of resistance should be endorsed and its practice should be inculcated at an earlier stage of the medical education.

The virulence of the organism, the risk of adverse effects and super infection as well as the immune status of the patient, were considered as the factors which deserved the most consideration before prescribing an antibiotic ${ }^{19}$. The ability of the antibiotic to promote resistance, the in-vitro antibiotic sensitivity of the causative organism and the pharmacokinetic profile of the antibiotic were given second priority. This demonstrates that the students were more aware and concerned about the individual patient's benefit and harm, the dangerous consequences which result to the society due the indiscriminate antibiotic use may not be obvious to them.

The students should be made aware of these important facts and a sense of responsibility should be nurtured, that as prescribers, they are not only responsible for the benefit and the welfare of their patients but also for the society at large.

Davenport LAP et al, data represent outcome-based education is said to be an important tool in which the requirements are explicitly defined in detail, to ensure that the medical graduates are fit for practice. This can be utilized for educating the students about antibiotics, so that as prescribers, they are fit to prescribe antibiotics, maximise their effective and efficient use and minimize the development of resistance. ${ }^{20}$

Steiner E et al, results were more correlated with our study apart from teaching about antibiotic prescribing, the principles of the protocol development for antibiotic use in health care facilities, should form an integral part of the undergraduate teaching. Small group exercises that facilitate the students in practising patient education skills such as negotiating with patients about the need for antibiotics and educating them about the proper use of antibiotics, should from an important part of the students' antibiotic curriculum. ${ }^{21}$

The medical education strategies should aim, not only to increase the knowledge, but also to change the behaviour and to improve the patient outcomes. They have to be tailored as per the youngster's development, capabilities and experience.

In spite of the lack of any formal training regarding antibiotics during their schooling or at the pre university level, the students who take admissions in the subjects which are related to the health sciences during their graduation, tend to have a better knowledge regarding antibiotics and their use as compared to the students who enter other streams. This proves that students exposed to similar curriculum, and having the same learning experience, due to their differing capabilities, interests and development may have different knowledge levels and attitudes.

Moreover, antibiotic resistance has been widely discussed and publicised in the press, media, on the online discussion forums and the general public are becoming knowledgeable about the issue of resistance. Since the media and the internet have become important sources of information, especially among the youth, they have become the medium of gaining knowledge and awareness regarding various public issues.

\section{CONCLUSION}

This study provides an important insight regarding the knowledge, attitudes and practices of medical students that, most of them were aware of the antimicrobial resistance and its consequences. The only concern was their casual attitude regarding the antibiotic use. Further educational interventions are necessary to improve their understanding and perceptions on antibiotic resistance, as well as their attitude towards antibiotic use. This has to be considered before planning for an effective undergraduate curriculum regarding antibiotic resistance and usage.

\section{ACKNOWLEDGEMENTS}

Authors would like to thank the students who participated in this study, for their input, dedication and enthusiasm.

\section{Funding: No funding sources Conflict of interest: None declared \\ Ethical approval: The study was approved by the Institutional Ethics Committee}

\section{REFERENCES}

1. Chen C, Chen YM, Hwang KL, Lin SJ, Yang CC, Tsay RW, et al. Behavior, attitudes and knowledge about antibiotic usage among residents of Changhua, Taiwan. J Microbiol Immunol Infect. 2005;38:53-9.

2. Srinivasan A, Song X, Richards A, SinkowitzCochran R, Cardo D, Rand C. A survey of knowledge, attitudes, and beliefs of house staff physicians from various specialties concerning antimicrobial use and resistance. Arch Intern Med. 2004;164:1451-6. 
3. Eng JV, Marcus R, Hadler JL, Imhoff B, Vugia DJ, Cieslak PR, et al. Consumer attitudes and use of antibiotics. Emerging Infec Dise. 2003 Sep;9(9):1128.

4. Azevedo MM, Pinheiro C, Yaphe J, Baltazar F. Portuguese students' knowledge of antibiotics: a cross-sectional study of secondary school and university students in Braga. BMC Public Health. 2009;9:359.

5. Wright EP, Jain P. Survey of antibiotic knowledge amongst final year medical students. Journal of Antimicrobial Chemotherapy. February. 2004;550-51.

6. Steinberg I. Clinical Choices of Antibiotics: Judging Judicious Use. The American Journal of Managed Care. Dec 2000;6(23):Sup.S1178-88.

7. Simpson SA, Wood F, Butler CC. General practitioners' perceptions of antimicrobial resistance: a qualitative study. J Antimic Chemother. 2007;59:292-6.

8. Guerra CM, Pereira CAP, Neto ARV, Cardo DM, Correa L. Physicians' perceptions, beliefs, attitudes, and knowledge concerning antimicrobial resistance in a Brazilian teaching hospital. Infect Control Hosp Epidemiol. 2007;28:1411-4.

9. Brown EM. Guidelines for antibiotic usage in hospitals. J Antimic Chemother. 202;49:587-92.

10. Wester CW, Durairaj L, Evans AT, Schwartz DN, Husain S, Martinez E. Antibiotic Resistance - A Survey of Physician Perceptions. Arch Intern Med. 2002;162:2210-16.

11. Sintchenko V, Iredell JR, Gilbert GL, Coiera E. What do physicians think about evidence-based antibiotic use in critical care? A survey of Australian intensivists and infectious disease practitioners. Intern MedJ. 2001;31:462-9.

12. Hsiao FY, Lee JA, Huang WF, Chen SM, Chen HY. Survey of medication knowledge and behaviors among college students in Taiwan. American J Pharmace Educa. 2006;70(2):Article 30.

13. Centers for Disease Control and Prevention (CDC). Get Smart: Know When Antibiotics Work. Available at: http://www.cdc.gov/getsmart/resources/quiz. html. Accessed on May 2011.

14. Thriemer K, Katuala Y, Batoko B, Alworonga JP, Devlieger H, Van Geet C, et al. Antibiotic prescribing in DR Congo: a knowledge, attitude and practice survey among medical doctors and students. PloS one. 2013 Feb 18;8(2):e55495.

15. Sellman JS, Decarolis D, Schullo-Feulner A, Nelson DB, Filice GA. Information resources used in antimicrobial prescribing. J Am Med Inform Assoc. 2004;11:281-4.

16. Zafar SN, Syed R, Waqar S, Zubairi AJ, Vaqar T, Shaikh M, et al. Self-medication amongst university students of Karachi: prevalence, knowledge and attitudes. J Paki Med Associat. 2008;58(4):214.

17. Nathwani D, Davey P. Antibiotic prescribing- are there lessons for physicians? J Med. 1999;92:5:28792.

18. Davey P, Garner S. Professional education on antimicrobial prescribing: a report from the Specialist Advisory Committee on Antimicrobial Resistance (SACAR) Professional Education Subgroup. J Antimicro Chemothe 2007;60(Suppl. 1):i27-i32.

19. Giblin TB, Sinkowitz-Cochran RL, Harris PL, Jacobs S, Liberatore K, Palfreyman MA, et al. Clinicians' perceptions of the problem of antimicrobial resistance in health care facilities. Arch Intern Med. 2004;164:1662-8.

20. Davenport LAP, Davey PG, Ker JS. An outcomebased approach for teaching prudent antimicrobial prescribing to undergraduate medical students: report of a Working Party of the British Society for Antimicrobial Chemotherapy. J Antimicro Chemothe. 2005;56:196-203.

21. Steiner E, Saddler LC, Fagnan LJ. Promoting appropriate antibiotic use: Teaching doctors, teaching patients. Calif J Heal Promo. 2004;2(Special Issue: Oregon):22-30.

Cite this article as: Regidi SR, Mallika BSB. Antibiotic resistance and usage, a survey on the knowledge, attitude and practices among the medical students of a southern Indian teaching hospitals. Int J Basic Clin Pharmacol 2019;8:1083-9. 


\section{Annexure 1: Questions included in a survey of KAP of MBBS-medical students regarding antibiotic} use and resistance.

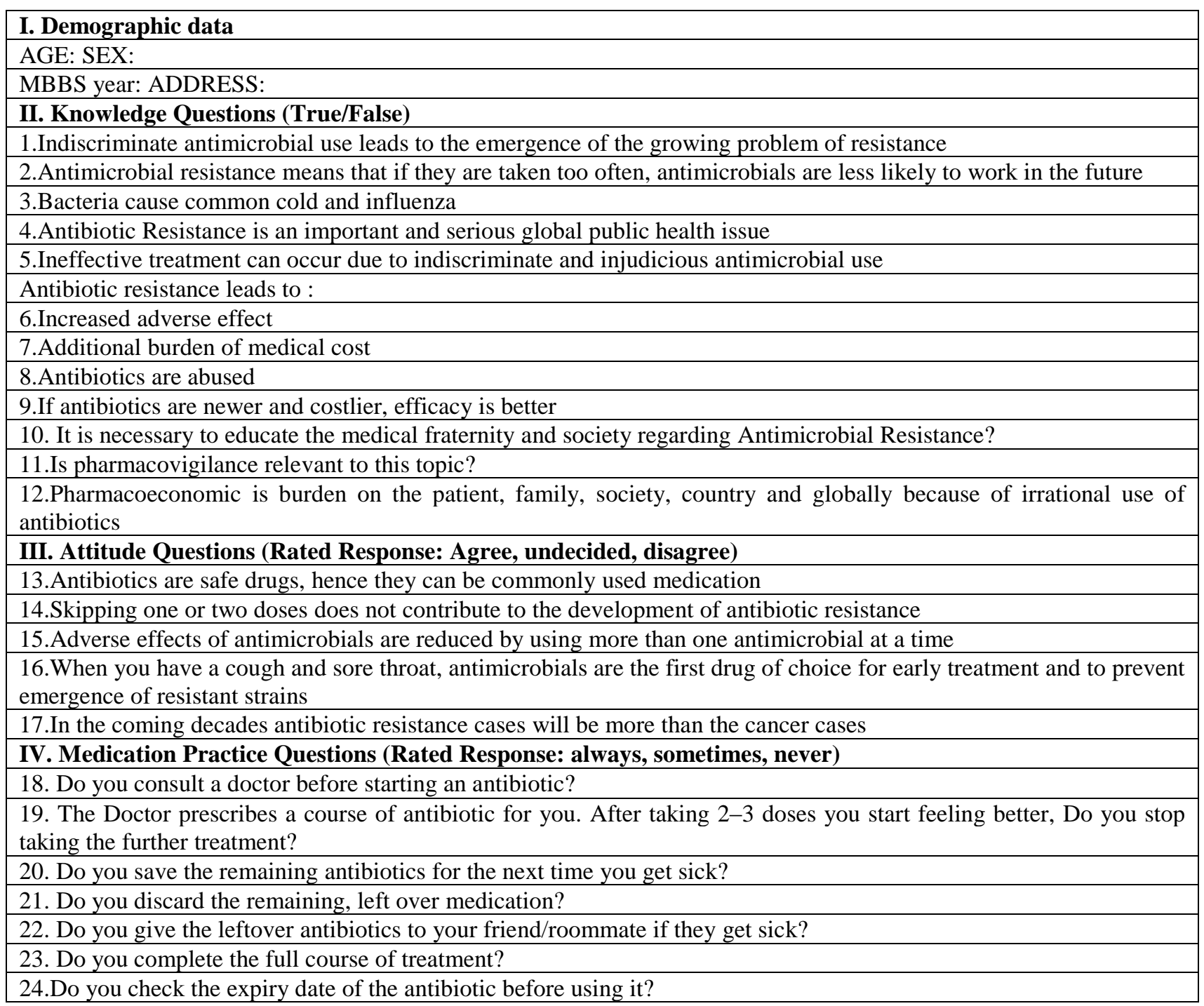

